\title{
Use of Analgesic and Sedative Drugs in the NICU: Integrating Clinical Trials and Laboratory Data
}

\author{
XAVIER DURRMEYER, LASZLO VUTSKITS, KANWALJEET J. S. ANAND, AND PETER C. RIMENSBERGER \\ Neonatal Intensive Care Unit [X.D.], Centre Hospitalier Intercommunal de Créteil, Créteil 94000, France; Departments of \\ Pediatrics [X.D., P.C.R.], Anesthesiology, Pharmacology, and Intensive Care [L.V.], and Neuroscience [L.V.], University Hospital \\ of Geneva, Geneva 1211, Switzerland; Department of Pediatrics [K.J.S.A.], University of Tennessee Health Science Center, \\ Memphis, Tennessee 38103
}

\begin{abstract}
Recent advances in neonatal intensive care include and are partly attributable to growing attention for comfort and pain control in the term and preterm infant requiring intensive care. Limitation of painful procedures is certainly possible, but most critically ill infants require unavoidable painful or stressful procedures such as intubation, mechanical ventilation, or catheterization. Many analgesics (opioids and nonsteroidal anti-inflammatory drugs) and sedatives (benzodiazepines and other anesthetic agents) are available but their use varies considerably among units. This review summarizes current experimental knowledge on the effects of sedative and analgesic drugs on brain development and reviews clinical evidence that speaks for or against the use of common analgesic and sedative drugs in the NICU but avoids any discussion of anesthesia during surgery. Risk/benefit ratios of intermittent boluses or continuous infusions for the commonly used sedative and analgesic agents are discussed in the light of clinical and experimental studies. The limitations of extrapolating experimental results from animals to humans must be considered while making practical recommendations based on the currently available evidence. (Pediatr Res 67: 117-127, 2010)
\end{abstract}

\section{Experimental Data on the Effects of Analgesics and Sedative Drugs During Central Nervous System Development}

Appropriate development of the CNS relies on the precise temporal-spatial orchestration of multifaceted molecular pathways guiding proliferation, migration, differentiation, and survival of neural cells. Interference with these finely tuned developmental mechanisms can disrupt physiologic developmental patterns, and might, ultimately, lead to permanent impairment of CNS functions. Analgesics and sedatives are potent modulators of several ionotropic and G-protein-linked receptor signaling pathways implicated in important morphogenetic events during brain development. The question of whether these drugs exert adverse effects on brain development when administered during pregnancy or in neonatal populations is of utmost importance. Experimental data de-

Received May 28, 2009; accepted October 14, 2009.

Correspondence: Peter C. Rimensberger, M.D., Department of Pediatrics, Pediatric and Neonatal Intensive Care Unit, University Hospital of Geneva, 6 Rue Willy Donzé, 1211 Geneva 14, Switzerland; e-mail: peter.rimensberger@hcuge.ch scribing the effects of analgesics or sedatives on the developing brain from in vitro (1-10) and in vivo (11-32) studies are summarized in Tables 1 and 2, respectively.

Opioid analgesics primarily act on $\mu$-, $\delta$-, and $\kappa$-types of opioid receptors on the cell surface. On agonist binding, all opioid receptor subtypes recruit inhibitory $G$ proteins $\left(\mathrm{G}_{\mathrm{i} / \mathrm{o}}\right)$ to initiate the activation of multiple intracellular signaling cascades $(33,34)$. In addition to analgesic effects, these signaling pathways are implicated in a variety of other biologic processes, including the modulation of proliferation, survival and differentiation of the neural stem cells, neurons, or glia that express opioid receptors (34).

A role for opioid receptor-mediated signaling in developmental processes is suggested by the early expression of opioid receptors in the developing rodent brain $(35,36)$. Chronic morphine exposure during the prenatal and early postnatal periods induces significant reductions in brain volume, neuronal packing density, and dendritic growth (15). Animals subjected to such treatment show long-term impairments in learning abilities and locomotor activity $(16,17)$. Furthermore, opioids modulate cell proliferation in germinative zones of the developing brain in a receptor-, brain region-, and cell type-specific manner (1,37-39) (see Tables 1 and 2 for specific effects). However, the role of opioid signaling in neural cell migration in the developing brain remains unknown up to date.

In contrast, opioid blockade by naltrexone leads to increases in brain size, suggesting that endogenous opioid signaling is associated with pruning during development (40). Naltrexoneinduced chronic opioid blockade in the early postnatal period significantly increases dendritic arborization and the number of dendritic spines, indicating that endogenous opioids are critical regulators of neuronal differentiation and growth (41). Application of selective $\mu$ receptor agonists increases nerve growth factor (NGF)-dependent survival of embryonic chick dorsal root ganglion neurons, suggesting that growth factormediated neuronal survival might be modulated by opioid signaling (42). Daily morphine treatment or repetitive inflam-

Abbreviations: COX, Cyclooxygenase 
Table 1. In vitro toxicity of sedative/analgesic drugs in the developing brain

\begin{tabular}{|c|c|c|}
\hline Drugs & Species & Results \\
\hline \multirow[t]{2}{*}{ Morphine } & Mouse & $\begin{array}{l}\text { Inhibition of DNA synthesis in the } \\
\text { developing cerebellum (1) }\end{array}$ \\
\hline & Rat & $\begin{array}{l}\text { High dose }(1 \mathrm{mM}) \text { inhibits neurite } \\
\text { elongation, low concentrations }(<10 \\
\mathrm{nM}) \text { enhance neurite promoting activity } \\
\text { of NGF (2) }\end{array}$ \\
\hline \multirow[t]{3}{*}{ Ketamine } & Rat & $\begin{array}{l}\text { Concentration-, age, and } \\
\text { duration-dependant apoptosis (3) }\end{array}$ \\
\hline & & $\begin{array}{l}\text { Prolonged exposition to low concentrations } \\
\text { impairs dendritic arborization }(4,5)\end{array}$ \\
\hline & Monkey & $\begin{array}{l}\text { Concentration-, age-, and } \\
\text { duration-dependant apoptosis (10) }\end{array}$ \\
\hline \multirow[t]{4}{*}{ Propofol } & Rat & $\begin{array}{l}\text { Concentration-, time-, and space-dependant } \\
\text { apoptosis (6) }\end{array}$ \\
\hline & & $\begin{array}{l}\text { Possibly irreversible lesions to GABAergic } \\
\text { neurons (7) }\end{array}$ \\
\hline & & Decreased dendritic growth (8) \\
\hline & Chick embryo & $\begin{array}{l}\text { Growth cone collapse and neurite } \\
\text { destruction (9) }\end{array}$ \\
\hline Midazolam & Rat & No effect on dendritic growth (8) \\
\hline
\end{tabular}

matory pain in postnatal rats (1-7 d) lead to long-term alterations in pain threshold, locomotor behavior, and alcohol preference during adulthood, but these changes are attenuated when the two treatments are combined (43). In the adult rat brain, however, high-opioid doses induce electroencephalographic seizure activity and cell death in several brain regions $(44,45)$

Acetaminophen and other nonsteroidal anti-inflammatory drugs (NSAID) inhibit cyclooxygenase (COX)-1 and COX-2 enzymes expressed in the CNS and peripheral organs (4648). COX-2 is expressed in distinct neuronal populations throughout the forebrain, and its expression in dendritic spines is dynamically regulated by NMDA-dependent synaptic activity $(48,49)$. In rodents, COX-2 expression is relatively low during the first 2 postnatal weeks and increases markedly from the third postnatal week, coinciding with the peak of synaptogenesis (50). In patients with Rett syndrome, a severe neurodevelopmental disorder characterized by impaired dendritic differentiation (51), the intensity of somatic and dendritic COX-2 immunostaining, and the number of COX-2 immunostained neurons are significantly reduced compared with neurologically normal controls (50). Whether pharmacological blockade of COX signaling using nonsteroidal antiinflammatory drugs can also interfere with neuronal differentiation remains unknown.

Most sedative drugs operate by ligand-gated ionotropic receptors to modulate the activity of different neurotransmitter systems (52). In addition to their roles in synaptic transmission, these neurotransmitters also act as epigenetic factors during development to control important biologic processes including progenitor cell proliferation, neuroblast migration, and neuronal differentiation (53). A delicate balance between excitatory and inhibitory signals plays a key role in the functional assembly of neuronal networks (54). Thus, the impact of sedative drugs on the development of activitydependent neuronal networks is possible because even small changes in the relative amounts of excitation and inhibition can markedly alter neuronal processing. An increasing number of experimental observations suggest potentially adverse effects of sedative drugs on the developing brain.

Ketamine. Ketamine primarily blocks NMDA-mediated neurotransmission by binding noncompetitively to the phencyclidine (PCP)-binding site of the NMDA receptor (55). Importantly, this drug also interacts with adenosinergic, monoaminergic, cholinergic, and opioidergic signaling pathways $(56,57)$. In rodents, duration of exposure to ketamine is critical $(19,20,58)$, and specific brain regions are particularly vulnerable to NMDA activation during critical periods of development (59). Results on the effects of a single bolus injection are controversial (Table 1) (22-24). Using in vitro culture of isolated GABAergic neurons from newborn rats, Vutskits et al. $(4,5)$ demonstrated that low, nonapoptogenic concentrations of ketamine interfere with dendritic arborization in these cells, potentially altering the development of neuronal networks. These rodent data were extended to primates, indicating apoptotic and necrotic cell death after prolonged ketamine exposure $(24 \mathrm{~h})$ on gestational d 122 and postnatal d 5 but not on postnatal d 35. Shorter ketamine exposure $(3 \mathrm{~h})$ did not lead to neuronal cell death in 5-d-old monkeys (25).

Benzodiazepines. Benzodiazepines selectively activate the $\mathrm{GABA}_{\mathrm{A}}$ receptor complex (60), which is functional from early developmental stages $(61,62)$. Chronic prenatal exposure of rat fetuses to diazepam results in long-term functional deficits and atypical behavioral patterns $(27,28)$. Exposure of 7-d-old mice to diazepam (10-30 mg/kg i.p.) induced widespread apoptosis in cortical and subcortical areas $(31,63)$, whereas lower doses $(5 \mathrm{mg} / \mathrm{kg})$ induced apoptosis only in the laterodorsal thalamus and did not lead to behavioral or cognitive impairments later in life (24). Prolonged diazepam treatment during the prenatal and the postnatal period also induce longlasting changes in $\mathrm{GABA}_{\mathrm{A}}$ receptors and neurosteroid levels (64-66). A single, subanesthetic dose of midazolam can induce neuroapoptosis in the cerebral cortex and basal ganglia of newborn mice (23). In newborn rats, midazolam potentiates nociceptive behavior, sensitizes cutaneous reflexes, and is devoid of any sedative effects (67). Whether neonatal exposure to midazolam also induces long-term behavioral or $\operatorname{cog}$ nitive deficits remains unknown.

Propofol. Propofol (2,6-diisopropyl phenol) is an alkyl phenol derivative dissolved in a lipid emulsion. This drug potentiates the effect of GABA by inducing tyrosine kinasemediated phosphorylation of the $\beta$ subunits of the GABAA receptor complex (68). Despite controversy $(69,70)$, this agent is commonly used in young children (71), including neonates (72). Toxicity of propofol for specific neurons has been shown in different in vitro and in vivo models (Table 2).

Barbiturates. Barbiturates are also potent agonists of the $\mathrm{GABA}_{\mathrm{A}}$ receptor. Exposure of 7-d-old rats to pentobarbital $(20-30 \mathrm{mg} / \mathrm{kg})$ or phenobarbital $(40-100 \mathrm{mg} / \mathrm{kg})$ for $5 \mathrm{~h}$ induced widespread neuronal apoptosis in the brain (31). In these experiments, neuronal death was associated with reduced expression of neurotrophins and other survivalpromoting proteins in the brain (31). In contrast, single doses 
Table 2. In vivo toxicity of sedative/analgesic drugs in the developing brain

\begin{tabular}{|c|c|c|c|c|}
\hline Drugs & Species & Experimental plan & Short-term effect & Long-term effect \\
\hline Morphine & Rats & $\begin{array}{l}\text { Chronic exposure in utero and } \\
\text { early postnatal days }\end{array}$ & $\begin{array}{l}\text { Decreased brain volume, neuronal } \\
\text { packing density, and dendritic } \\
\text { growth (11-15) }\end{array}$ & $\begin{array}{l}\text { Long-term impairments in learning } \\
\text { abilities and motor activity }(16,17)\end{array}$ \\
\hline Fentanyl & Mouse & 3 injections & $\begin{array}{l}\text { Exacerbation of ibotenate-induced } \\
\text { white matter lesions (18) }\end{array}$ & \\
\hline Sufentanil & Mouse & 3 injections & $\begin{array}{l}\text { No exacerbation of ibotenate-induced } \\
\text { white matter lesions (18) }\end{array}$ & \\
\hline \multirow[t]{4}{*}{ Ketamine } & Rats & Single dose & No adverse effect $(19,20)$ & \\
\hline & & $\begin{array}{l}\text { Repeated high doses }(5-20 \mathrm{mg} / \mathrm{kg}) \text {. } \\
\text { Repeated low doses }(2.5 \mathrm{mg} / \mathrm{kg})\end{array}$ & $\begin{array}{l}\text { Inconstant neuronal degeneration } \\
(19-21,59) \text {. Neuroprotective effects } \\
(21,32)\end{array}$ & $\begin{array}{l}\text { No adverse effects. Improvement of } \\
\text { pain-induced excitotoxicity and } \\
\text { long-term cognitive impairments (21) }\end{array}$ \\
\hline & Mouse & Single dose & Inconstant neuronal apoptosis (22-24) & $\begin{array}{l}\text { No gross behavioral consequences (22). } \\
\text { Disrupted spontaneous activity and } \\
\text { learning (24) }\end{array}$ \\
\hline & Rhesus monkey & 24 h continuous i.v. & $\begin{array}{l}\text { Neuronal cell death inversely } \\
\text { proportional to developmental stage } \\
(25)\end{array}$ & \\
\hline \multirow[t]{2}{*}{ Diazepam } & Rat & In utero chronic exposure & & Altered behavior (26-28) \\
\hline & Mouse & Single dose & Partial neurodegeneration (29) & No behavioral impairment (29) \\
\hline \multirow[t]{2}{*}{ Midazolam } & Rat & Single dose & No increase in neuronal apoptosis (30) & \\
\hline & Mouse & Single dose & Neuronal apoptosis (23) & \\
\hline Propofol & Mouse & Single dose & $\begin{array}{l}\text { Dose-dependent neuronal apoptosis } \\
\text { (24) }\end{array}$ & No or minor behavioral change (24) \\
\hline Thiopental & Mouse & Single dose & $\begin{array}{l}\text { No neuronal apoptosis if used alone } \\
\text { (24) }\end{array}$ & No or minor behavioral change (24) \\
\hline Phenobarbital & Rat & $\begin{array}{l}\text { "Plasma concentrations relevant for } \\
\text { seizure control in humans" }\end{array}$ & Neuronal apoptosis (31) & \\
\hline
\end{tabular}

of thiopental $(5-25 \mathrm{mg} / \mathrm{kg})$ did not induce neurodegeneration in the CNS (24).

Combined use of sedative agents. In the NICU, children are often exposed to combinations of different analgesics and sedatives either simultaneously or sequentially, to reduce potential side effects. Most drugs have GABA-mimetic and/or NMDA antagonist properties, raising the question of whether combined use of sedative drugs has additive or synergistic neurotoxic effects $(30,73)$. For example, coadministration of even low concentrations of ketamine and nitrous oxide synergistically enhances their neurotoxic effects (74). Sedative concentrations of midazolam and ketamine induce apoptosis in the infant mouse brain more effectively than either of these drugs alone (23). Coadministration of ketamine with propofol or thiopental also potentiates apoptotic neurodegeneration in young rodents (24). Exposure of 7-d-old rats to midazolamnitrous oxide-isoflurane anesthesia for $6 \mathrm{~h}$ led to widespread neurodegeneration and this was accompanied by persistent learning deficits (30). Anesthesia-induced activation of apoptotic pathways in immature neurons implicates significant changes in the expression pattern of brain-derived neurotrophic factor (BDNF) in the brain of rat pups (75).

\section{Extrapolation of Laboratory Results to Clinical Practice}

To evaluate the clinical relevance of experimental observations claiming drug-induced neurotoxicity in the developing brain is difficult. The first critical issue concerns the extrapolation of appropriate developmental stages from different animal species to humans. For decades, it has been considered that brain development in 7-d-old mice and rats, the focus of most experimental studies, corresponds approximately to the human brain at 32-36 wk of GA (76). Recent work, however, suggests that the 7-d-old rodent brain is equivalent to the human brain at 17-20 wk of GA (77). For neuronal circuit formation, the peak synaptogenic period in humans takes place between the third trimester of pregnancy and the first few years of postnatal life $(78,79)$, whereas, in rodents, this period is situated between the second and fourth postnatal weeks (80). Clearly, further experiments are needed to elucidate the impact of sedative drugs on the developing CNS at later stages of development.

Another related concern is that there are important developmental changes in receptor subunit composition of major neurotransmitter systems during the brain growth spurt. This strongly determines the functional modalities of neurotransmission and might fundamentally influence the impact of drugs on the developing CNS. In fact, embryonic/early postnatal $\mathrm{GABA}_{\mathrm{A}}$ receptors differ markedly from those expressed in the adult rodent brain (81-84). For example, in most brain areas, the $\alpha 3$ subunits along with $\beta 2, \beta 3$, and $\gamma 2$ subunits are the most prominent components of the $\mathrm{GABA}_{\mathrm{A}}$ receptor complex throughout prenatal and early postnatal development (82). Similarly, other receptor populations, such as NMDA and opioid receptors, also have developmentally regulated subunit composition or subtype expression profiles (85-87) imparting different functional properties to these receptor populations.

Furthermore, GABAergic signaling has the unique property of "ionic plasticity," which is based on short- and long-term changes in the $\mathrm{Cl}^{-}$and $\mathrm{HCO}^{3-}$ ion concentrations in postsynaptic neurons. Although short-term ionic plasticity is caused by activity-dependent, channel-mediated anion shifts, long- 
term ionic plasticity depends on changes in the expression patterns and kinetic regulation of molecules involved in anion homeostasis (88). During development, activation of $\mathrm{GABA}_{\mathrm{A}}$ receptors leads to neuronal depolarization because of the high intracellular $\mathrm{Cl}^{-}$concentrations. Thus, GABA acts as an excitatory neurotransmitter during brain development. The functional switch toward the hyperpolarizing actions of this neurotransmitter is linked to the developmental expression of the $\mathrm{K}^{+}-\mathrm{Cl}^{-}$cotransporter ( $\mathrm{KCC} 2$ ), actively extruding intracellular $\mathrm{Cl}^{-}$from neurons (88). KCC2 appears during the second postnatal week in the rodent cerebral cortex (89) and from the 30th gestational week in humans (90). These data raise the intriguing possibility that exposure of premature babies to GABAergic agents would exert excitatory effects on the developing brain (67).

The possibility of interspecies differences in terms of drug effects cannot be excluded (91). In addition to rodents, however, anesthetic and subanesthetic doses of currently used anesthetics also induce apoptosis in other species such as guinea pigs (92) and monkeys (25). Another essential criticism concerns the relatively long exposure time needed to produce detectable neurotoxic effects in the majority of laboratory studies (93). From a developmental perspective, 6 h-long exposures to anesthetics in rodents would be equivalent to producing general anesthesia for 2-3 wk in the human neonate (94). However, recent results showing that even a single exposure to subanesthetic doses of anesthetics could trigger 2- to 4-fold increases in neuronal apoptosis in the mouse brain somewhat counteract these arguments (23). The rat brain may be vulnerable during specific developmental periods; in contrast, ketamine administration just before birth has beneficial effects on subsequent learning in young and adult rats (95).

New in vitro data indicate that short-term exposure to sedative drugs can also impair neuronal development by interfering with dendritic growth and branching without inducing cell death $(4,5,8)$. Given the importance of neuronal dendritic architecture in appropriate information processing, one essential next step will be to determine how neuronal dendritic arborization is influenced by anesthetics. These experiments, combined with long-term assessment of behavioral outcomes after short-term sedation, would probably help us to better understand the impact of sedative drugs on CNS development.

Differences in anesthetic concentrations of drugs across different species further complicate the issue of drug-induced developmental neurotoxicity. For example, subanesthetic plasma concentrations of ketamine in humans are around $0.1-0.5 \mu \mathrm{g} / \mathrm{mL}(96,97)$, whereas doses of $3 \mathrm{mg} / \mathrm{kg}$ i.v. to induce anesthesia were associated with blood levels of 1-2 $\mu \mathrm{g} / \mathrm{mL}(98,99)$. In contrast, as high as $40 \mathrm{mg} / \mathrm{kg}$ of ketamine s.c. was insufficient to produce anesthesia in young mice (23). Plasma levels of ketamine around $6 \mu \mathrm{g} / \mathrm{mL}$ occurred after a single s.c. dose of ketamine $20 \mathrm{mg} / \mathrm{kg}$ (20). Altogether, these data suggest that effective plasma concentrations, and probably "on-site" brain concentrations as well, are significantly higher in rodents compared with humans, raising further difficulties in the extrapolation of these experiments to human infants.
Finally, one can argue that these experimental conditions are very different from those associated with surgical anesthesia and complex perioperative management, including intensive care (93). First, based on the neuronal stimulation hypothesis (100), preoperative stress and painful stimuli during surgery can activate NMDA and other excitatory receptors in the immature brain and anesthetic drugs could thus reduce extreme degrees of neuronal excitation (101). In line with this hypothesis, clinical doses of ketamine $(2.5 \mathrm{mg} / \mathrm{kg})$ reduced cell death after inflammatory pain in the newborn rat brain (21). The average clinical situation is in contrast to experimental settings where anesthesia was administered without painful stimuli and, consequently, the effect of anesthetics on the suppression of basal neural activity was evaluated. Clearly, further experimental studies are needed to better elucidate this issue. Second, human neonates and children routinely receive nutritional support and metabolic monitoring in the perioperative period, thus minimizing the risk for hypoglycemia and impaired nutrition. In contrast, rodent pups do not suckle well after general anesthesia, resulting in a prolonged decrease in weight gain compared with nonanesthetized littermates (19). Given that the role of malnutrition in decreased brain growth and learning disabilities is well established $(102,103)$, one cannot exclude the possibility that neurotoxic effects of anesthetics in animal studies are, at least partially, related to impaired nutrition in the perioperative period.

\section{Existing Human Data on Neurotoxicity of Sedative Drugs Used in the NICU}

Although neurotoxicity has been studied extensively in animal models, intense controversy exists about whether drugs used for sedation in the NICU cause cellular brain damage in human neonates [see previous report (73)]. The possible deleterious effects of sedative/analgesic drugs on brain development can be categorized in two groups: direct toxicity due to pharmacological effects of the drug on immature neurons and developmental pathways; indirect toxicity due to adverse events such as respiratory depression, hypotension, bradycardia, or hypoxemia potentially causing brain lesions.

No prospective clinical trial has ever addressed this issue in the newborn. Two retrospective studies evaluated the longterm effects of sedation or analgesia in preterm infants hospitalized in the NICU. The first study (104) evaluated neurologic outcome at 5-6 y in survivors from two randomized controlled trials, investigating morphine use in the early 1990s $(105,106)$. No differences occurred between infants exposed and nonexposed to morphine, although the rates of death or disability in both groups were high (in the range of $40 \%$ for both), corresponding to commonly reported clinical outcomes in the presurfactant era. Another retrospective study compared 5 -y neurodevelopmental outcomes between infants born $<33$ wk GA in 1997 exposed or not exposed to sedation for $7 \mathrm{~d}$ or more during mechanical ventilation and/or surgery (107). Although this study has limitation, after adjustment for gestational age and propensity, prolonged sedation was not associated with poor neurologic outcomes at $5 \mathrm{y}$. In term infants 
suffering from hypoxic-ischemic encephalopathy, a retrospective study reported that postnatal morphine use was associated with improved outcomes, based on psychological assessments and neuroimaging studies (108). In the light of these findings, further data analyses of clinical trials examining the use of hypothermia should also investigate the effects of concomitant sedative or analgesic therapy on long-term neurodevelopmental outcomes (109-111).

Although sedative drugs might induce significant physiologic perturbations, due to depression of respiratory and circulatory systems, and that this can also be held responsible for later brain impairment, safety issues have only been studied for very few drugs in the newborn.

Opioids. In the NEOPAIN (Neurologic Outcomes and Preemptive Analgesics in Neonates) trial (112), after subgroup analysis of patients who received or did not receive open-label analgesia, continuous morphine infusion did not increase vulnerability of ventilated preterm neonates to adverse neurologic events. Those who were hypotensive before morphine therapy and those receiving doses higher than $10 \mu \mathrm{g} / \mathrm{kg} / \mathrm{h}$ morphine (27-29 wk subgroup) were more likely to develop hypotension, similar to what has been reported by Simons et al. (113) subsequently. The use of volume expanders and vasopressor drugs was similar in the two study groups in both trials, and no relationship among morphine use, blood pressure variability, and intraventricular hemorrhage (IVH) could be determined.

Midazolam. Continuous infusion of midazolam significantly decreased blood pressures in one randomized controlled trial (114) and was related to an increase in IVH in another one (115). Midazolam decreases cerebral blood flow velocity (116). A meta-analysis concluded that midazolam should not be used routinely in ventilated preterm newborns because it prolongs length of stay in the NICU and potentially may cause harmful neurologic effects (117). For endotracheal intubation, the only randomized controlled trial evaluating midazolam combined with atropine in one arm had to be terminated early because of frequent severe adverse events in the midazolam group (118). When midazolam was combined with remifentanil in a small cohort, no major side effects were reported (119).

Barbiturates. Phenobarbital use in ventilated infants has been associated to an increase in air leaks (120) and an increased need for mechanical ventilation (121). However, ventilation strategies were not detailed in these studies, what renders interpretation of these findings difficult. Thiopental provided effective sedation for tracheal intubation but did not decrease the incidence of desaturations $(122,123)$.

Ketamine. Systemic and cerebral hemodynamic effects of ketamine were assessed when used as analgesic therapy for central vein catheterization. No impairment of hemodynamics could be shown (124). When used for short procedures, higher doses of ketamine $(2 \mathrm{mg} / \mathrm{kg})$ reduced heart rate (125) and 5 $\mathrm{mg} / \mathrm{kg}$ reduced blood pressure without impairing cardiac output (124). Studies of infants undergoing cardiac catheterization have reported respiratory complications (126) and increased blood pressure (127).

Propofol. Propofol use for tracheal intubation in premature infants caused no hemodynamic adverse events and no highgrade intracranial hemorrhages were seen on brain ultrasound performed after drug administration (72). However, other studies reported hypotension, apnea, respiratory obstruction, and transient myoclonus in infants receiving propofol (128-131).

\section{Recommendations for Clinical Practice Based on the Best Available Evidence}

Evidence from randomized controlled trials (RCT), systematic reviews, or from large observational studies was synthesized to develop practical recommendations for analgesia/ sedation in different settings such as mechanical ventilation, postoperative analgesia, endotracheal intubation, or other painful procedures. Efficacy and safety issues are summarized in Table 3 for continuous analgesia/sedation and in Table 4 for intermittent analgesia/sedation. These data should be interpreted while keeping in mind that methods for assessment of prolonged pain in preterm newborns are underdeveloped (132), whereas those for acute pain are well established (133). A stepwise approach to pain management is represented in Figure 1. Proposed drug doses in different preterm populations are summarized in Table 5. The doses listed in Table 5 are extracted from the clinical studies reviewed in the text and Tables 3 and 4. Well-designed pharmacological studies are sparse in the newborn, especially in preterm infants. Most of the published data only assess pharmacokinetic issues without considering efficacy. These recommendations are therefore based on safe doses reported in published clinical trials. When several doses are reported, we selected and recommend the lowest effective doses.

\section{Practical Recommendations for Mechanical Ventilation}

Routine use of morphine or fentanyl cannot be recommended for ventilated preterm neonates because no obvious beneficial long-term effects have been proven (134). The analgesic effect is difficult to quantify as illustrated by the high rate of open-label morphine use in some trials (112). Particular caution must be exercised in the most immature infants (under 26 wk GA) or those with preexisting hypotension. Doses $>10$ $\mu \mathrm{g} / \mathrm{kg} / \mathrm{h}$ should be used with caution because of potential hemodynamic, respiratory, and neurologic adverse effects. Fentanyl is a faster-acting and shorter-lasting drug when compared with morphine but limited safety data are available (135-138) and concerns have been raised about opioid tolerance and withdrawal (139). Other derivatives of fentanyl require additional investigations.

The routine use of midazolam (117) or barbiturates (121) cannot be recommended. As a potentially harmful drug, midazolam should be prescribed with extreme caution $(116,140,141)$. Midazolam is often used as additional treatment when analgesia is considered insufficient or as a means to decrease analgesic use but no evidence supports this practice in the neonate. Experimental data suggest, however, that midazolam lacks sedative or analgesic effects in the neonatal period (67). Moreover, combination of midazolam with opioids has been associated with hypotension, apnea, and hypoxemia in preterm infants (142). 
Table 3. Risk/benefit data for continuous analgesia and/or sedation in the newborn infant

\begin{tabular}{|c|c|c|c|}
\hline Drugs & Populations & Efficacy & $\begin{array}{c}\text { Clinical safety data, actual or theoretical } \\
\text { risk, and unknowns }\end{array}$ \\
\hline \multicolumn{4}{|c|}{ Mechanical ventilation } \\
\hline \multirow[t]{3}{*}{ Morphine } & $23-32$ wks GA & Pain scores inconsistently decreased (134) & Prolongation of ventilation (134) \\
\hline & & & $\begin{array}{l}\text { Possible hypotensive effect in the most } \\
\text { immature infants for doses }>10 \mu \mathrm{g} / \mathrm{kg} / \mathrm{h} \\
(112,113)\end{array}$ \\
\hline & & & Rare long-term outcome available (104) \\
\hline \multirow[t]{5}{*}{ Fentanyl } & $26-36$ wks GA & $\begin{array}{c}\text { Constant significant decrease in physiological } \\
\text { or behavioral stress or pain markers }(136)\end{array}$ & Reduced stress hormones (136) \\
\hline & & & $\begin{array}{l}\text { Preserved gastrointestinal motility (dose: } 1 \\
\quad \mu \mathrm{g} / \mathrm{kg} / \mathrm{h}) \text { vs morphine (137) }\end{array}$ \\
\hline & & & $\begin{array}{l}\text { Increased ventilatory pressures (dose: } 5 \mu \mathrm{g} / \mathrm{kg} \\
\text { bolus then } 2 \mu \mathrm{g} / \mathrm{kg} / \mathrm{h})(136)\end{array}$ \\
\hline & & & $\begin{array}{l}\text { No improvement in short-term outcomes } \\
\text { (136) }\end{array}$ \\
\hline & & & $\begin{array}{l}\text { No assessment of long-term outcomes } \\
\text { available }\end{array}$ \\
\hline \multirow[t]{3}{*}{ Midazolam } & 24 wks-term & Inconstantly improved sedation $(114,115)$ & $\begin{array}{l}\text { Worse neurological outcomes }(200 \mu \mathrm{g} / \mathrm{kg} \\
\text { bolus then } 20-60 \mu \mathrm{g} / \mathrm{kg} / \mathrm{h})(115)\end{array}$ \\
\hline & & & Hypotension (30 or $60 \mu \mathrm{g} / \mathrm{kg} / \mathrm{h}$ ) (114) \\
\hline & & & $\begin{array}{l}\text { Decreased cerebral blood flow velocity ( } 200 \\
\mu \mathrm{g} / \mathrm{kg} \text { bolus then } 200 \mu \mathrm{g} / \mathrm{kg} / \mathrm{h})(116)\end{array}$ \\
\hline \multirow[t]{2}{*}{ Barbiturates } & $\mathrm{BW}<1750 \mathrm{~g}$ & No reliable efficiency study & $\begin{array}{l}\text { Increase in air leaks }(2 \times 10 \mathrm{mg} / \mathrm{kg} / 12 \mathrm{~h} \text { then } \\
2.5 \mathrm{mg} / \mathrm{kg} / 12 \mathrm{~h})(120)\end{array}$ \\
\hline & & & $\begin{array}{l}\text { Increased need for mechanical ventilation } \\
\text { (121) }\end{array}$ \\
\hline \multicolumn{4}{|c|}{ Postoperative analgesia } \\
\hline Morphine & $>35$ wks $\mathrm{BW}>1500 \mathrm{~g}$ & $\begin{array}{l}\text { Effective analgesia with same cumulative } \\
\text { doses when used continuously or as } \\
\text { intermittent bolus doses (143-145) }\end{array}$ & $\begin{array}{l}\text { Mainly respiratory side effects (mean doses } \\
10 \mu \mathrm{g} / \mathrm{kg} / \mathrm{h})(143-145) \text {. No assessment of } \\
\text { long term outcomes }\end{array}$ \\
\hline Fentanyl & $>36 \mathrm{wks}$ & Effective analgesia (146) & $\begin{array}{l}\text { Excessive apnea if given as bolus }(2 \mu \mathrm{g} / \mathrm{kg} / 2 \\
\text { h) (146) }\end{array}$ \\
\hline \multirow[t]{2}{*}{ Acetaminophen } & $\geq 36$ wks & No effect on acute pain (147) & \\
\hline & $\mathrm{BW} \geq 1500 \mathrm{~g}$ & No decrease in morphine requirements (148) & \\
\hline NSAIDs & $\begin{array}{l}\text { Term-aged former preterm } \\
\text { infants }\end{array}$ & $\begin{array}{l}\text { Diminished opioid use in one short } \\
\text { descriptive study (150) }\end{array}$ & Lack of experience \\
\hline
\end{tabular}

BW, birth weight.

\section{Practical Recommendations for Postoperative Analgesia}

Morphine (143-145) or fentanyl (146) is effective at decreasing postoperative pain, usually recommended in continuous infusions for safety and simplicity reasons, although careful attention to dosing and respiratory monitoring is imperative. Considering current knowledge of routine use of paracetamol cannot be recommended in newborns $(147,148)$ despite good hepatic tolerance (149). NSAIDs are an interesting alternative to opioids avoiding respiratory, hemodynamic, and digestive complications (150). However, they deserve additional investigation before they can be routinely prescribed. Routine sedation cannot be recommended for postoperative newborns.

\section{Practical Recommendations for Endotracheal Intubation}

To date, the most documented regimen associates an opioid with a muscle blocker (151). Fast-acting opioids, such as fentanyl (152-154), are probably more appropriate than morphine $(155,156)$. Despite encouraging results, the paucity of available data for alfentanil $(157)$ and remifentanil $(119,158)$ imposes limitations on the use of these drugs.

Propofol certainly offers good intubating conditions and has the advantage of being a single, easy to prepare drug (72).
However, complementary data should be collected before generalization of its use. Barbiturates have never been compared with opioids in a randomized trial, although thiopental provided effective sedation for tracheal intubation without decreasing episodes of desaturations $(122,123)$. Although midazolam is widely used in clinical practice, it cannot be recommended as the drug of choice for intubation, especially when not combined with an analgesic (118).

A key question conditioning a drug's choice is what is considered the optimal time for surfactant administration? If prophylactic surfactant is given, there is usually no time or venous access for premedication before intubation in the delivery room (159). If surfactant is administered later, then the optimal use of analgesic drugs should not interfere with the planned extubation time.

\section{Practical Recommendations for Procedural Pain Relief}

The most effective method to reduce neonatal pain or discomfort is to reduce the number of procedures performed and the episodes of patient handling (160). NICUs and nurseries should develop strategies that limit handling and procedures but do not compromise the care of the infants. When 
Table 4. Clinical trials data for intermittent analgesia and/or sedation in the newborn infant

\begin{tabular}{|c|c|c|c|}
\hline Drugs & Populations & Efficacy & $\begin{array}{l}\text { Clinical safety data, actual or theoretical } \\
\text { risk, and unknowns }\end{array}$ \\
\hline \multicolumn{4}{|l|}{ Endotracheal intubation } \\
\hline Morphine & $25-40$ wks GA & $\begin{array}{l}\text { Number of attempts inconsistently } \\
\text { decreased. Hypoxemia episodes or } \\
\text { duration unchanged }(155,156)\end{array}$ & $\begin{array}{l}\text { Possibly inappropriate delay in the onset } \\
\text { of action (too slow) (100 or } 200 \mu \mathrm{g} / \mathrm{kg} \text { ) }\end{array}$ \\
\hline Fentanyl & $500-4990$ g 24-42 wks GA & $\begin{array}{l}\text { Rare complications, high success rate } \\
\text { at first attempt (152-154). } \\
\text { Addition of placebo vs } \\
\text { mivacurium improves intubation } \\
\text { conditions and tolerance (154) }\end{array}$ & $\begin{array}{l}\text { No deleterious effect on general or } \\
\text { cerebral hemodynamics }(3 \mu \mathrm{g} / \mathrm{kg}) \\
\text { (138). No adverse effect on respiratory } \\
\text { compliance }(4 \mu \mathrm{g} / \mathrm{kg})(135)\end{array}$ \\
\hline $\begin{array}{l}\text { Fentanyl-related synthetic } \\
\text { opioids }\end{array}$ & $>28$ wks GA $>1000 \mathrm{~g}$ & $\begin{array}{l}\text { Improved intubation conditions with } \\
\text { alfentanil (157) and remifentanil } \\
(119,158)\end{array}$ & $\begin{array}{l}\text { Chest wall rigidity, frequent hypoxemia. } \\
\text { No data available }\end{array}$ \\
\hline Midazolam & Not mentioned & $\begin{array}{l}\text { Trial terminated early because of } \\
\text { frequent severe adverse events in } \\
\text { the midazolam + atropine group } \\
\text { ( } 29 \% \text { patients required } \\
\text { cardiopulmonary resuscitation) } \\
\text { (118) }\end{array}$ & $\begin{array}{l}\text { Decreased mean arterial pressure and } \\
\text { cerebral blood flow velocity (100 or } \\
200 \mu \mathrm{g} / \mathrm{kg})(116,140,141)\end{array}$ \\
\hline Barbiturates & $>2000 \mathrm{~g}>32$ wks GA & $\begin{array}{l}\text { Reduction in heart rate and blood } \\
\text { pressure }(122,123)\end{array}$ & $\begin{array}{l}\text { Frequency of desaturations similar to } \\
\text { placebo }(5 \text { or } 6 \mathrm{mg} / \mathrm{kg})(122,123)\end{array}$ \\
\hline Propofol & 25-30 wks GA & $\begin{array}{l}\text { Faster and more frequently } \\
\text { successful intubation higher } \\
\text { median oxygen saturations } v s \\
\text { atropine/morphine/suxamethonium } \\
\text { (72) }\end{array}$ & $\begin{array}{l}\text { Questionable control group (see morphine } \\
\text { efficacy earlier) }\end{array}$ \\
\hline Ketamine & $28-36$ wks GA, $N=3$ & Not specifically assessed & $\begin{array}{l}\text { No cerebral hemodynamic adverse effects } \\
\quad(5 \mathrm{mg} / \mathrm{kg})(124)\end{array}$ \\
\hline \multicolumn{4}{|l|}{ Other invasive procedures } \\
\hline Morphine & $\begin{array}{l}\text { 23-32 wks GA. Mainly intubated } \\
\text { infants }\end{array}$ & $\begin{array}{l}\text { Inconsistent efficacy for heel lance } \\
\text { procedure }(165,166) \text { Inconsistent } \\
\text { efficacy for tracheal suction } \\
(112,115) \text {. Some efficacy for } \\
\text { PCVC insertion }(168)\end{array}$ & $\begin{array}{l}\text { Increased cerebral blood flow }(50 \mu \mathrm{g} / \mathrm{kg}) \\
\quad(116)\end{array}$ \\
\hline $\begin{array}{l}\text { Fentanyl-related synthetic } \\
\text { opioids }\end{array}$ & 29-36 wks GA $<32$ wks GA & $\begin{array}{l}\text { Alfentanil efficient for tracheal } \\
\text { suction but frequent thoracic } \\
\text { rigidity (167). Remifentanil } \\
\text { decreased pain for PICC insertion } \\
\text { (169) }\end{array}$ & $\begin{array}{l}\text { Thoracic rigidity requiring muscle blocker } \\
\text { injection (alfentanil } 20 \mu \mathrm{g} / \mathrm{kg} \text { ) (167). } \\
\text { Same time to complete the maneuver } \\
\text { and procedure time as placebo (169) }\end{array}$ \\
\hline Acetaminophen & $\geq 37$ wks GA & No effect for heel lance (170) & Good hepatic tolerance (149) \\
\hline Ketamine & & $\begin{array}{l}\text { Ineffective for tracheal suctioning } \\
\text { (125) }\end{array}$ & $\begin{array}{l}\text { No cerebral hemodynamic adverse effect } \\
\quad(5 \mathrm{mg} / \mathrm{kg})(124)\end{array}$ \\
\hline
\end{tabular}

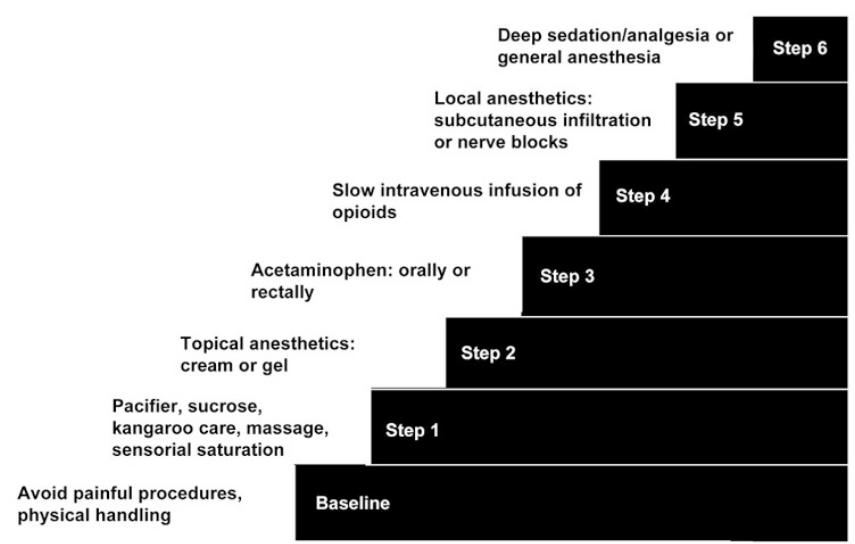

Figure 1. Stepwise approach to neonatal analgesia.

needed the use of nonpharmacological approaches, such as sucrose (161), massage (162), kangaroo care (163), or sensorial saturation (164), are currently considered safe and effec- tive for analgesia and should be considered the first line of treatment.

Whether an opioid should be added remains controversial. Conflicting results have been reported in the use of morphine for procedures such as heel lance $(165,166)$ or tracheal suctioning $(112,115)$. During tracheal suctioning, alfentanil was found to be effective but induced frequent thoracic rigidity (167), whereas ketamine was found to be inappropriate (125). For percutaneous central venous catheter (PCVC) placement, morphine provided good analgesia but induced mild respiratory depression (168). Remifentanil showed promising results during PCVC insertion (169) but requires additional investigation. All other treatments (170) cannot be routinely recommended considering the current evidence.

\section{Remaining Urgent Questions and Perspectives}

Clinicians should not forget that multiple lines of evidence suggest the necessity of analgesia and sedation in infants. 
Table 5. Proposed drug doses for analgesia/sedation in the NICU (surgical anesthesia not included)

\begin{tabular}{|c|c|c|c|}
\hline Drug & $<28$ wks GA & $28-32$ wks GA & $>32$ wks GA \\
\hline \multicolumn{4}{|l|}{ Morphine } \\
\hline Continuous & $\begin{array}{l}\text { Loading dose } 5-15 \mu \mathrm{g} / \mathrm{kg} \text { over } 1 \mathrm{~h} \text { then } \\
5-10 \mu \mathrm{g} / \mathrm{kg} / \mathrm{h}\end{array}$ & $\begin{array}{l}\text { Loading dose } 15-25 \mu \mathrm{g} / \mathrm{kg} \text { over } 1 \mathrm{~h} \text { then } \\
5-15 \mu \mathrm{g} / \mathrm{kg} / \mathrm{h}\end{array}$ & $\begin{array}{l}\text { Loading dose } 25-50 \mu \mathrm{g} / \mathrm{kg} \text { over } 1 \mathrm{~h} \\
\text { then } 5-20 \mu \mathrm{g} / \mathrm{kg} / \mathrm{h}\end{array}$ \\
\hline \multicolumn{4}{|l|}{ Fentanyl } \\
\hline Continuous & No available data & $\begin{array}{l}\text { Optional loading dose } 1-2 \mu \mathrm{g} / \mathrm{kg} \text { over } 10-20 \\
\min \text { then } 0.5-2 \mu \mathrm{g} / \mathrm{kg} / \mathrm{h}\end{array}$ & \\
\hline Continuous & No available data & $\begin{array}{l}\text { Loading dose } 0.1-0.5 \mu \mathrm{g} / \mathrm{kg} \text { over } 10-20 \mathrm{~min} \\
\text { then } 0.05-0.2 \mu \mathrm{g} / \mathrm{kg} / \mathrm{h}\end{array}$ & \\
\hline Transient & & No available data & \\
\hline \multicolumn{4}{|l|}{ Alfentanil } \\
\hline Continuous & & No available data & \\
\hline Transient & No available data & $3-10 \mu \mathrm{g} / \mathrm{kg}$ & \\
\hline Continuous & $\begin{array}{l}\text { Optional loading dose } 50-200 \mu \mathrm{g} / \mathrm{kg} \\
\text { then } 10-20 \mu \mathrm{g} / \mathrm{kg} / \mathrm{h}\end{array}$ & $\begin{array}{l}\text { Optional loading dose } 50-200 \mu \mathrm{g} / \mathrm{kg} \text { then } 20 \\
\text { to } 40 \mu \mathrm{g} / \mathrm{kg} / \mathrm{h}\end{array}$ & $\begin{array}{l}\text { Optional loading dose } 50-200 \mu \mathrm{g} / \mathrm{kg} \\
\text { then } 20-50 \mu \mathrm{g} / \mathrm{kg} / \mathrm{h}\end{array}$ \\
\hline Transient & $\begin{array}{l}\text { No available data-should not be used as } \\
\text { a single agent for tracheal intubation }\end{array}$ & & \\
\hline \multicolumn{4}{|l|}{ Thiopental } \\
\hline Continuous & $\begin{array}{l}\text { Loading dose } 1-2 \mathrm{mg} / \mathrm{kg} \text { then } 0.5-2.5 \\
\mathrm{mg} / \mathrm{kg} / \mathrm{h}\end{array}$ & & \\
\hline Transient & No available data & $1-4 \mathrm{mg} / \mathrm{kg}$ & \\
\hline \multicolumn{4}{|l|}{ Propofol } \\
\hline Continuous & $\begin{array}{l}\text { Should not be used as continuous } \\
\text { sedation in the neonate }\end{array}$ & & \\
\hline Transient & $1-2.5 \mathrm{mg} / \mathrm{kg}$, possibly repeated once & & \\
\hline
\end{tabular}

Repetitive painful stimuli may persistently alter pain processing in humans (171), and epidemiologic studies have revealed an association between peri- and neonatal complications and behavioral/emotional problems in childhood, anxiety/ depression, and even suicidal tendencies (172,173). Conversely, drug toxicity should not be underestimated and risk/ benefit balance must be evaluated when prescribing analgesia or sedation for neonates. First-line treatment is the decrease in painful procedures that are still extremely frequent in the NICU (160). Nonpharmacological analgesia should be considered when moderate pain is expected. Neonatal units should establish and follow protocols indicating recommended drugs according to the expected intensity and duration of pain resulting from invasive procedures.

Basic research should focus on physiologic mechanisms involved in pain and brain development. At the same time, development of experimental models should aim at creating situations as close as possible to clinical settings, e.g. proper oxygenation during drug administration, optimized nutrition, and exposure of animals to painful situations as recently proposed (21).

Clinical research should focus on long-term evaluation of neurodevelopmental outcome of newborns hospitalized in NICUs with particular attention to the drugs used. Although many confounding factors (e.g. underlying pathologies and social conditions) are usually implicated, large population studies could provide sufficient statistical power to generate novel hypotheses. Long-term follow-up of infants included in large prospective studies on pain control would also provide precious data.

As for all clinical decisions, the risk/benefit balance should be carefully addressed when considering analgesic or sedative treatment in a neonate, using currently available data and keeping in mind the major research gaps remaining in this field.

\section{REFERENCES}

1. Hauser KF, Houdi AA, Turbek CS, Elde RP, Maxson W III 2000 Opioids intrinsically inhibit the genesis of mouse cerebellar granule neuron precursors in vitro: differential impact of mu and delta receptor activation on proliferation and neurite elongation. Eur J Neurosci 12:1281-1293

2. Tenconi B, Lesma E, DiGiulio AM, Gorio A 1996 High opioid doses inhibit whereas low doses enhance neuritogenesis in PC12 cells. Brain Res Dev Brain Res 94:175-181

3. Wang C, Sadovova N, Fu X, Schmued L, Scallet A, Hanig J, Slikker W 2005 The role of the $N$-methyl-D-aspartate receptor in ketamine-induced apoptosis in rat forebrain culture. Neuroscience 132:967-977

4. Vutskits L, Gascon E, Tassonyi E, Kiss JZ 2006 Effect of ketamine on dendritic arbor development and survival of immature GABAergic neurons in vitro. Toxicol Sci 91:540-549

5. Vutskits L, Gascon E, Potter G, Tassonyi E, Kiss JZ 2007 Low concentrations of ketamine initiate dendritic atrophy of differentiated GABAergic neurons in culture. Toxicology 234:216-226 
6. Spahr-Schopfer I, Vutskits L, Toni N, Buchs PA, Parisi L, Muller D 2000 Differential neurotoxic effects of propofol on dissociated cortical cells and organotypic hippocampal cultures. Anesthesiology 92:1408-1417

7. Honegger P, Matthieu JM 1996 Selective toxicity of the general anesthetic propofol for GABAergic neurons in rat brain cell cultures. J Neurosci Res 45:631-636

8. Vutskits L, Gascon E, Tassonyi E, Kiss JZ 2005 Clinically relevant concentrations of propofol but not midazolam alter in vitro dendritic development of isolated gamma-aminobutyric acid-positive interneurons. Anesthesiology 102:970-976

9. Al-Jahdari WS, Saito S, Nakano T, Goto F 2006 Propofol induces growth cone collapse and neurite retractions in chick explant culture. Can J Anaesth 53:10781085

10. Wang C, Sadovova N, Hotchkiss C, Fu X, Scallet AC, Patterson TA, Hanig J, Paule MG, Slikker W Jr 2006 Blockade of $N$-methyl-D-aspartate receptors by ketamine produces loss of postnatal day 3 monkey frontal cortical neurons in culture. Toxicol Sci 91:192-201

11. Zagon IS, McLaughlin PJ 1977 Morphine and brain growth retardation in the rat. Pharmacology 15:276-282

12. Ford DH, Rhines RK 1979 Prenatal exposure to methadone HCL in relationship to body and brain growth in the rat. Acta Neurol Scand 59:248-262

13. Hammer RP Jr, Ricalde AA, Seatriz JV 1989 Effects of opiates on brain development. Neurotoxicology 10:475-483

14. Ricalde AA, Hammer RP Jr 1990 Perinatal opiate treatment delays growth of cortical dendrites. Neurosci Lett 115:137-143

15. Seatriz JV, Hammer RP Jr 1993 Effects of opiates on neuronal development in the rat cerebral cortex. Brain Res Bull 30:523-527

16. Zagon IS, McLaughlin PJ, Thompson CI 1979 Development of motor activity in young rats following perinatal methadone exposure. Pharmacol Biochem Behav 10:743-749

17. Zagon IS, McLaughlin PJ, Thompson CI 1979 Learning ability in adult female rats perinatally exposed to methadone. Pharmacol Biochem Behav 10:889-894

18. Laudenbach V, Calo G, Guerrini R, Lamboley G, Benoist JF, Evrard P, Gressens P 2001 Nociceptin/orphanin FQ exacerbates excitotoxic white-matter lesions in the murine neonatal brain. J Clin Invest 107:457-466

19. Hayashi H, Dikkes P, Soriano SG 2002 Repeated administration of ketamine may lead to neuronal degeneration in the developing rat brain. Paediatr Anaesth $12: 770-774$

20. Scallet AC, Schmued LC, Slikker W Jr, Grunberg N, Faustino PJ, Davis H, Lester D, Pine PS, Sistare F, Hanig JP 2004 Developmental neurotoxicity of ketamine: morphometric confirmation, exposure parameters, and multiple fluorescent labeling of apoptotic neurons. Toxicol Sci 81:364-370

21. Anand KJ, Garg S, Rovnaghi CR, Narsinghani U, Bhutta AT, Hall RW 2007 Ketamine reduces the cell death following inflammatory pain in newborn rat brain. Pediatr Res 62:283-290

22. Rudin M, Ben-Abraham R, Gazit V, Tendler Y, Tashlykov V, Katz Y 2005 Single-dose ketamine administration induces apoptosis in neonatal mouse brain. J Basic Clin Physiol Pharmacol 16:231-243

23. Young C, Jevtovic-Todorovic V, Qin YQ, Tenkova T, Wang H, Labruyere J, Olney JW 2005 Potential of ketamine and midazolam, individually or in combination, to induce apoptotic neurodegeneration in the infant mouse brain. $\mathrm{Br} \mathrm{J}$ Pharmacol 146:189-197

24. Fredriksson A, Ponten E, Gordh T, Eriksson P 2007 Neonatal exposure to a combination of $N$-methyl-D-aspartate and gamma-aminobutyric acid type A receptor anesthetic agents potentiates apoptotic neurodegeneration and persistent behavioral deficits. Anesthesiology 107:427-436

25. Slikker W Jr, Zou X, Hotchkiss CE, Divine RL, Sadovova N, Twaddle NC, Doerge DR, Scallet AC, Patterson TA, Hanig JP, Paule MG, Wang C 2007 Ketamineinduced neuronal cell death in the perinatal rhesus monkey. Toxicol Sci 98:145158

26. Kellogg C, Tervo D, Ison J, Parisi T, Miller RK 1980 Prenatal exposure to diazepam alters behavioral development in rats. Science 207:205-207

27. Kellogg CK, Simmons RD, Miller RK, Ison JR 1985 Prenatal diazepam exposure in rats: long-lasting functional changes in the offspring. Neurobehav Toxicol Teratol 7:483-488

28. Simmons RD, Miller RK, Kellogg CK 1984 Prenatal exposure to diazepam alters central and peripheral responses to stress in adult rat offspring. Brain Res 307:39-46

29. Fredriksson A, Archer T, Alm H, Gordh T, Eriksson P 2004 Neurofunctional deficits and potentiated apoptosis by neonatal NMDA antagonist administration. Behav Brain Res 153:367-376

30. Jevtovic-Todorovic V, Hartman RE, Izumi Y, Benshoff ND, Dikranian K, Zorumski CF, Olney JW, Wozniak DF 2003 Early exposure to common anesthetic agents causes widespread neurodegeneration in the developing rat brain and persistent learning deficits. J Neurosci 23:876-882

31. Bittigau P, Sifringer M, Genz K, Reith E, Pospischil D, Govindarajalu S, Dzietko M, Pesditschek S, Mai I, Dikranian K, Olney JW, Ikonomidou C 2002 Antiepileptic drugs and apoptotic neurodegeneration in the developing brain. Proc Natl Acad Sci USA 99:15089-15094

32. Rovnaghi CR, Garg S, Hall RW, Bhutta AT, Anand KJ 2008 Ketamine analgesia for inflammatory pain in neonatal rats: a factorial randomized trial examining long-term effects. Behav Brain Funct 4:35

33. Milligan G 2005 Opioid receptors and their interacting proteins. Neuromolecular Med 7:51-59

34. Tegeder I, Geisslinger G 2004 Opioids as modulators of cell death and survivalunraveling mechanisms and revealing new indications. Pharmacol Rev 56:351-369

35. Zhu Y, Hsu MS, Pintar JE 1998 Developmental expression of the mu, kappa, and delta opioid receptor mRNAs in mouse. J Neurosci 18:2538-2549
36. Georges F, Normand E, Bloch B, Le Moine C 1998 Opioid receptor gene expression in the rat brain during ontogeny, with special reference to the mesostriatal system: an in situ hybridization study. Brain Res Dev Brain Res 109:187199

37. Reznikov K, Hauser KF, Nazarevskaja G, Trunova Y, Derjabin V, Bakalkin G 1999 Opioids modulate cell division in the germinal zone of the late embryonic neocortex. Eur J Neurosci 11:2711-2719

38. Knapp PE, Maderspach K, Hauser KF 1998 Endogenous opioid system in developing normal and jimpy oligodendrocytes: mu and kappa opioid receptors mediate differential mitogenic and growth responses. Glia 22:189-201

39. Sargeant TJ, Day DJ, Mrkusich EM, Foo DF, Miller JH 2007 Mu opioid receptor are expressed on radial glia but not migrating neuroblasts in the late embryonic mouse brain. Brain Res 1175:28-38

40. Zagon IS, McLaughlin PJ 1983 Increased brain size and cellular content in infant rats treated with an opiate antagonist. Science 221:1179-1180

41. Hauser KF, McLaughlin PJ, Zagon IS 1987 Endogenous opioids regulate dendritic growth and spine formation in developing rat brain. Brain Res 416:157-161

42. Sakaguchi M, Fujimori T, Satoh T, Satoh M, Takeuchi M, Matsumura E 1999 Effects of opioids on neuronal survival in culture of embryonic chick dorsal root ganglion neurons. Neurosci Lett 262:17-20

43. Bhutta AT, Rovnaghi C, Simpson PM, Gossett JM, Scalzo FM, Anand KJ 2001 Interactions of inflammatory pain and morphine in infant rats: long-term behavioral effects. Physiol Behav 73:51-58

44. Kofke WA, Garman RH, Stiller RL, Rose ME, Garman R 1996 Opioid neurotoxicity: fentanyl dose-response effects in rats. Anesth Analg 83:1298-1306

45. Kofke WA, Garman RH, Garman R, Rose M 2000 Opioid neurotoxicity: role of neurotransmitter systems. Neurol Res 22:733-737

46. Hertting G, Seregi A 1989 Formation and function of eicosanoids in the central nervous system. Ann NY Acad Sci 559:84-99

47. O'Neill GP, Ford-Hutchinson AW 1993 Expression of mRNA for cyclooxygenase-1 and cyclooxygenase-2 in human tissues. FEBS Lett 330:156-160

48. Yamagata K, Andreasson KI, Kaufmann WE, Barnes CA, Worley PF 1993 Expression of a mitogen-inducible cyclooxygenase in brain neurons: regulation by synaptic activity and glucocorticoids. Neuron 11:371-386

49. Kaufmann WE, Worley PF, Pegg J, Bremer M, Isakson P 1996 COX-2, a synaptically induced enzyme, is expressed by excitatory neurons at postsynaptic sites in rat cerebral cortex. Proc Natl Acad Sci USA 93:2317-2321

50. Kaufmann WE, Worley PF, Taylor CV, Bremer M, Isakson PC 1997 Cyclooxygenase-2 expression during rat neocortical development and in Rett syndrome. Brain Dev 19:25-34

51. Kaufmann WE, Moser HW 2000 Dendritic anomalies in disorders associated with mental retardation. Cereb Cortex 10:981-991

52. Yamakura T, Bertaccini E, Trudell JR, Harris RA 2001 Anesthetics and ion channels: molecular models and sites of action. Annu Rev Pharmacol Toxicol 41:23-51

53. Represa A, Ben-Ari Y 2005 Trophic actions of GABA on neuronal development. Trends Neurosci 28:278-283

54. Liu G 2004 Local structural balance and functional interaction of excitatory and inhibitory synapses in hippocampal dendrites. Nat Neurosci 7:373-379

55. Oye I, Paulsen O, Maurset A 1992 Effects of ketamine on sensory perception: evidence for a role of $\mathrm{N}$-methyl-D-aspartate receptors. J Pharmacol Exp Ther 260:1209-1213

56. Adams HA 1998 Mechanisms of action of ketamine. Anaesthesiol Reanim 23:60-63

57. Mazar J, Rogachev B, Shaked G, Ziv NY, Czeiger D, Chaimovitz C, Zlotnik M, Mukmenev I, Byk G, Douvdevani A 2005 Involvement of adenosine in the antiinflammatory action of ketamine. Anesthesiology 102:1174-1181

58. Zou X, Patterson TA, Sadovova N, Twaddle NC, Doerge DR, Zhang X, Fu X, Hanig JP, Paule MG, Slikker W, Wang C 2009 Potential neurotoxicity of ketamine in the developing rat brain. Toxicol Sci 108:149-158

59. Ikonomidou C, Bosch F, Miksa M, Bittigau P, Vockler J, Dikranian K, Tenkova TI, Stefovska V, Turski L, Olney JW 1999 Blockade of NMDA receptors and apoptotic neurodegeneration in the developing brain. Science 283:70-74

60. Rudolph U, Antkowiak B 2004 Molecular and neuronal substrates for general anaesthetics. Nat Rev Neurosci 5:709-720

61. Fiszman ML, Behar T, Lange GD, Smith SV, Novotny EA, Barker JL 1993 GABAergic cells and signals appear together in the early post-mitotic period of telencephalic and striatal development. Brain Res Dev Brain Res 73:243-251

62. Lauder JM, Han VK, Henderson P, Verdoorn T, Towle AC 1986 Prenatal ontogeny of the GABAergic system in the rat brain: an immunocytochemical study. Neuroscience 19:465-493

63. Ikonomidou C, Bittigau P, Ishimaru MJ, Wozniak DF, Koch C, Genz K, Price MT, Stefovska V, Horster F, Tenkova T, Dikranian K, Olney JW 2000 Ethanol-induced apoptotic neurodegeneration and fetal alcohol syndrome. Science 287:1056-1060

64. Roberts AA, Pleger GL, Kellogg CK 2001 Effect of prenatal exposure to diazepam on brain GABA(A) receptor mRNA levels in rats examined at late fetal or adult ages. Dev Neurosci 23:135-144

65. Raol YH, Zhang G, Budreck EC, Brooks-Kayal AR 2005 Long-term effects of diazepam and phenobarbital treatment during development on GABA receptors, transporters and glutamic acid decarboxylase. Neuroscience 132:399-407

66. Martire M, Altobelli D, Cannizzaro C, Maurizi S, Preziosi P 2002 Prenatal diazepam exposure functionally alters the $\operatorname{GABA}(\mathrm{A})$ receptor that modulates $[3 \mathrm{H}]$ noradrenaline release from rat hippocampal synaptosomes. Dev Neurosci $24: 71-78$ 
67. Koch SC, Fitzgerald M, Hathway GJ 2008 Midazolam potentiates nociceptive behavior, sensitizes cutaneous reflexes, and is devoid of sedative action in neonatal rats. Anesthesiology 108:122-129

68. Bjornstrom K, Sjolander A, Schippert A, Eintrei C 2002 A tyrosine kinase regulates propofol-induced modulation of the beta-subunit of the GABA(A) receptor and release of intracellular calcium in cortical rat neurones. Acta Physiol Scand 175:227-235

69. Crawford MW, Dodgson BG, Holtby HH, Roy WL 2003 Propofol syndrome in children. CMAJ 168:669; author reply 669-670

70. Wooltorton E 2002 Propofol: contraindicated for sedation of pediatric intensive care patients. CMAJ 167:507

71. Murat I, Billard V, Vernois J, Zaouter M, Marsol P, Souron R, Farinotti R 1996 Pharmacokinetics of propofol after a single dose in children aged 1-3 years with minor burns. Comparison of three data analysis approaches. Anesthesiology $84: 526-532$

72. Ghanta S, Abdel-Latif ME, Lui K, Ravindranathan H, Awad J, Oei J 2007 Propofol compared with the morphine, atropine, and suxamethonium regimen as induction agents for neonatal endotracheal intubation: a randomized, controlled trial. Pediatrics 119:e1248-e1255

73. Mellon RD, Simone AF, Rappaport BA 2007 Use of anesthetic agents in neonates and young children. Anesth Analg 104:509-520

74. Jevtovic-Todorovic V, Benshoff N, Olney JW 2000 Ketamine potentiates cerebrocortical damage induced by the common anaesthetic agent nitrous oxide in adult rats. Br J Pharmacol 130:1692-1698

75. Lu LX, Yon JH, Carter LB, Jevtovic-Todorovic V 2006 General anesthesia activates BDNF-dependent neuroapoptosis in the developing rat brain. Apoptosis $11: 1603-1615$

76. Hagberg H, Peebles D, Mallard C 2002 Models of white matter injury: comparison of infectious, hypoxic-ischemic, and excitotoxic insults. Ment Retard Dev Disabil Res Rev 8:30-38

77. Clancy B, Finlay BL, Darlington RB, Anand KJ 2007 Extrapolating brain development from experimental species to humans. Neurotoxicology 28:931-937

78. Dobbing J, Sands J 1979 Comparative aspects of the brain growth spurt. Early Hum Dev 3:79-83

79. Huttenlocher PR, Dabholkar AS 1997 Regional differences in synaptogenesis in human cerebral cortex. J Comp Neurol 387:167-178

80. De Felipe J, Marco P, Fairen A, Jones EG 1997 Inhibitory synaptogenesis in mouse somatosensory cortex. Cereb Cortex 7:619-634

81. Poulter MO, Barker JL, O'Carroll AM, Lolait SJ, Mahan LC 1992 Differential and transient expression of GABAA receptor alpha-subunit mRNAs in the developing rat CNS. J Neurosci 12:2888-2900

82. Laurie DJ, Wisden W, Seeburg PH 1992 The distribution of thirteen GABAA receptor subunit mRNAs in the rat brain. III. Embryonic and postnatal development. J Neurosci 12:4151-4172

83. Hutcheon B, Fritschy JM, Poulter MO 2004 Organization of GABA receptor alpha-subunit clustering in the developing rat neocortex and hippocampus. Eur J Neurosci 19:2475-2487

84. Yu ZY, Wang W, Fritschy JM, Witte OW, Redecker C 2006 Changes in neocortical and hippocampal GABAA receptor subunit distribution during brain maturation and aging. Brain Res 1099:73-81

85. Cull-Candy S, Brickley S, Farrant M 2001 NMDA receptor subunits: diversity, development and disease. Curr Opin Neurobiol 11:327-335

86. Chahal H, D'Souza SW, Barson AJ, Slater P 1998 Modulation by magnesium of $N$-methyl-D-aspartate receptors in developing human brain. Arch Dis Child Fetal Neonatal Ed 78:F116-F120

87. Rahman W, Dashwood MR, Fitzgerald M, Aynsley-Green A, Dickenson AH 1998 Postnatal development of multiple opioid receptors in the spinal cord and development of spinal morphine analgesia. Brain Res Dev Brain Res 108:239-254

88. Rivera C, Voipio J, Kaila K 2005 Two developmental switches in GABAergic signalling: the $\mathrm{K}+-\mathrm{Cl}-$ cotransporter $\mathrm{KCC} 2$ and carbonic anhydrase CAVII. J Physiol 562:27-36

89. Lu J, Karadsheh M, Delpire E 1999 Developmental regulation of the neuronalspecific isoform of $\mathrm{K}-\mathrm{Cl}$ cotransporter $\mathrm{KCC} 2$ in postnatal rat brains. J Neurobiol 39:558-568

90. Vanhatalo S, Palva JM, Andersson S, Rivera C, Voipio J, Kaila K 2005 Slow endogenous activity transients and developmental expression of $\mathrm{K}+-\mathrm{Cl}$ - cotransporter 2 in the immature human cortex. Eur J Neurosci 22:2799-2804

91. Berde C, Cairns B 2000 Developmental pharmacology across species: promise and problems. Anesth Analg 91:1-5

92. Rizzi S, Carter LB, Ori C, Jevtovic-Todorovic V 2008 Clinical anesthesia causes permanent damage to the fetal guinea pig brain. Brain Pathol 18:198-210

93. Anand KJ, Soriano SG 2004 Anesthetic agents and the immature brain: are these toxic or therapeutic? Anesthesiology 101:527-530

94. Clancy B, Darlington RB, Finlay BL 2001 Translating developmental time across mammalian species. Neuroscience 105:7-17

95. Mickley GA, Kenmuir CL, McMullen CA, Snyder A, Yocom AM, Likins-Fowler D, Valentine EL, Weber B, Biada JM 2004 Long-term age-dependent behavioral changes following a single episode of fetal $N$-methyl-D-Aspartate (NMDA) receptor blockade. BMC Pharmacol 4:28

96. Roytblat L, Talmor D, Rachinsky M, Greemberg L, Pekar A, Appelbaum A, Gurman GM, Shapira Y, Duvdenani A 1998 Ketamine attenuates the interleukin-6 response after cardiopulmonary bypass. Anesth Analg 87:266-271

97. Zilberstein G, Levy R, Rachinsky M, Fisher A, Greemberg L, Shapira Y, Appelbaum A, Roytblat L 2002 Ketamine attenuates neutrophil activation after cardiopulmonary bypass. Anesth Analg 95:531-536; table of contents
98. Malinovsky JM, Servin F, Cozian A, Lepage JY, Pinaud M 1996 Ketamine and norketamine plasma concentrations after i.v., nasal and rectal administration in children. Br J Anaesth 77:203-207

99. Weber F, Wulf H, Gruber M, Biallas R 2004 S-ketamine and s-norketamine plasma concentrations after nasal and i.v. administration in anesthetized children. Paediat Anaesth 14:983-988

100. Lipton SA, Nakanishi N 1999 Shakespeare in love-with NMDA receptors? Nat Med 5:270-271

101. Bhutta AT, Anand KJ 2002 Vulnerability of the developing brain. Neurona mechanisms. Clin Perinatol 29:357-372

102. Dobbing J 1970 Undernutrition and the developing brain. The relevance of animal models to the human problem. Am J Dis Child 120:411-415

103. Lucas A, Morley R, Cole TJ 1998 Randomised trial of early diet in preterm babies and later intelligence quotient. BMJ 317:1481-1487

104. MacGregor R, Evans D, Sugden D, Gaussen T, Levene M 1998 Outcome at 5-6 years of prematurely born children who received morphine as neonates. Arch Dis Child Fetal Neonatal Ed 79:F40-F43

105. Quinn MW, Otoo F, Rushforth JA, Dean HG, Puntis JW, Wild J, Levene MI 1992 Effect of morphine and pancuronium on the stress response in ventilated preterm infants. Early Hum Dev 30:241-248

106. Quinn MW, Wild J, Dean HG, Hartley R, Rushforth JA, Puntis JW, Levene MI 1993 Randomised double-blind controlled trial of effect of morphine on catecholamine concentrations in ventilated pre-term babies. Lancet 342:324-327

107. Roze JC, Denizot S, Carbajal R, Ancel PY, Kaminski M, Arnaud C, Truffert P, Marret S, Matis J, Thiriez G, Cambonie G, Andre M, Larroque B, Breart G 2008 Prolonged sedation and/or analgesia and 5-year neurodevelopment outcome in very preterm infants: results from the EPIPAGE cohort. Arch Pediatr Adolesc Med $162: 728-733$

108. Angeles DM, Wycliffe N, Michelson D, Holshouser BA, Deming DD, Pearce WJ, Sowers LC, Ashwal S 2005 Use of opioids in asphyxiated term neonates: effects on neuroimaging and clinical outcome. Pediatr Res 57:873-878

109. Eicher DJ, Wagner CL, Katikaneni LP, Hulsey TC, Bass WT, Kaufman DA, Horgan MJ, Languani S, Bhatia JJ, Givelichian LM, Sankaran K, Yager JY 2005 Moderate hypothermia in neonatal encephalopathy: efficacy outcomes. Pediatr Neurol 32:11-17

110. Gluckman PD, Wyatt JS, Azzopardi D, Ballard R, Edwards AD, Ferriero DM, Polin RA, Robertson CM, Thoresen M, Whitelaw A, Gunn AJ 2005 Selective head cooling with mild systemic hypothermia after neonatal encephalopathy: multicentre randomised trial. Lancet 365:663-670

111. Shankaran S, Laptook AR, Ehrenkranz RA, Tyson JE, McDonald SA, Donovan EF, Fanaroff AA, Poole WK, Wright LL, Higgins RD, Finer NN, Carlo WA, Duara S, Oh W, Cotten CM, Stevenson DK, Stoll BJ, Lemons JA, Guillet R, Jobe AH 2005 Whole-body hypothermia for neonates with hypoxic-ischemic encephalopathy. N Engl J Med 353:1574-1584

112. Anand KJ, Hall RW, Desai N, Shephard B, Bergqvist LL, Young TE, Boyle EM, Carbajal R, Bhutani VK, Moore MB, Kronsberg SS, Barton BA 2004 Effects of morphine analgesia in ventilated preterm neonates: primary outcomes from the NEOPAIN randomised trial. Lancet 363:1673-1682

113. Simons SH, Roofthooft DW, van Dijk M, van Lingen RA, Duivenvoorden HJ, van den Anker JN, Tibboel D 2006 Morphine in ventilated neonates: its effects on arterial blood pressure. Arch Dis Child Fetal Neonatal Ed 91:F46-F51

114. Jacqz-Aigrain E, Daoud P, Burtin P, Desplanques L, Beaufils F 1994 Placebocontrolled trial of midazolam sedation in mechanically ventilated newborn babies. Lancet 344:646-650

115. Anand KJ, Barton BA, McIntosh N, Lagercrantz H, Pelausa E, Young TE, Vasa R 1999 Analgesia and sedation in preterm neonates who require ventilatory support: results from the NOPAIN trial. Neonatal Outcome and Prolonged Analgesia in Neonates. Arch Pediatr Adolesc Med 153:331-338

116. van Alfen-van der Velden AA, Hopman JC, Klaessens JH, Feuth T, Sengers RC, Liem KD 2006 Effects of midazolam and morphine on cerebral oxygenation and hemodynamics in ventilated premature infants. Biol Neonate 90:197-202

117. $\mathrm{Ng} \mathrm{E}$, Taddio A, Ohlsson A 2003 Intravenous midazolam infusion for sedation of infants in the neonatal intensive care unit. Cochrane Database Syst Rev CD002052

118. Attardi DM, Paul DA, Tuttle DJ, Greenspan JS 2000 Premedication for intubation in neonates. Arch Dis Child Fetal Neonatal Ed 83:F161

119. Pereira e Silva Y, Gomez RS, Marcatto Jde O, Maximo TA, Barbosa RF, Simoes e Silva AC 2007 Morphine versus remifentanil for intubating preterm neonates. Arch Dis Child Fetal Neonatal Ed 92:F293-F294

120. Kuban KC, Leviton A, Brown ER, Krishnamoorthy K, Baglivo J, Sullivan KF Allred E 1987 Respiratory complications in low-birth-weight infants who received phenobarbital. Am J Dis Child 141:996-999

121. Whitelaw A, Odd D 2007 Postnatal phenobarbital for the prevention of intraven tricular hemorrhage in preterm infants. Cochrane Database Syst Rev CD001691

122. Millar C, Bissonnette B 1994 Awake intubation increases intracranial pressure without affecting cerebral blood flow velocity in infants. Can J Anaesth 41:281-287

123. Bhutada A, Sahni R, Rastogi S, Wung JT 2000 Randomised controlled trial of thiopental for intubation in neonates. Arch Dis Child Fetal Neonatal Ed 82:F34F37

124. Betremieux P, Carre P, Pladys P, Roze O, Lefrancois C, Malledant Y 1993 Dopple ultrasound assessment of the effects of ketamine on neonatal cerebral circulation. Dev Pharmacol Ther 20:9-13

125. Saarenmaa E, Neuvonen PJ, Huttunen P, Fellman V 2001 Ketamine for procedura pain relief in newborn infants. Arch Dis Child Fetal Neonatal Ed 85:F53-F56

126. Malviya S, Burrows FA, Johnston AE, Benson LN 1989 Anaesthetic experience with paediatric interventional cardiology. Can J Anaesth 36:320-324 
127. Oklu E, Bulutcu FS, Yalcin Y, Ozbek U, Cakali E, Bayindir O 2003 Which anesthetic agent alters the hemodynamic status during pediatric catheterization? Comparison of propofol versus ketamine. J Cardiothorac Vasc Anesth 17:686-690

128. Gelber O, Gal M, Katz Y 1997 Clonic convulsions in a neonate after propofol anaesthesia. Paediatr Anaesth 7:88

129. Hertzog JH, Campbell JK, Dalton HJ, Hauser GJ 1999 Propofol anesthesia for invasive procedures in ambulatory and hospitalized children: experience in the pediatric intensive care unit. Pediatrics 103:E30

130. Rigby-Jones AE, Nolan JA, Priston MJ, Wright PM, Sneyd JR, Wolf AR 2002 Pharmacokinetics of propofol infusions in critically ill neonates, infants, and children in an intensive care unit. Anesthesiology 97:1393-1400

131. Vardi A, Salem Y, Padeh S, Paret G, Barzilay Z 2002 Is propofol safe for procedural sedation in children? A prospective evaluation of propofol versus ketamine in pediatric critical care. Crit Care Med 30:1231-1236

132. Boyle EM, Freer Y, Wong CM, McIntosh N, Anand KJ 2006 Assessment of persistent pain or distress and adequacy of analgesia in preterm ventilated infants. Pain 124:87-91

133. Anand KJ 2007 Pain assessment in preterm neonates. Pediatrics 119:605-607

134. Bellu R, de Waal KA, Zanini R 2008 Opioids for neonates receiving mechanical ventilation. Cochrane Database Syst Rev CD004212

135. Irazuzta J, Pascucci R, Perlman N, Wessel D 1993 Effects of fentanyl administration on respiratory system compliance in infants. Crit Care Med 21:1001-1004

136. Orsini AJ, Leef KH, Costarino A, Dettorre MD, Stefano JL 1996 Routine use of fentanyl infusions for pain and stress reduction in infants with respiratory distress syndrome. J Pediatr 129:140-145

137. Saarenmaa E, Huttunen P, Leppaluoto J, Meretoja O, Fellman V 1999 Advantages of fentanyl over morphine in analgesia for ventilated newborn infants after birth: a randomized trial. J Pediatr 134:144-150

138. Hamon I, Hascoet JM, Debbiche A, Vert P 1996 Effects of fentanyl administration on general and cerebral haemodynamics in sick newborn infants. Acta Paediatr 85:361-365

139. Franck LS, Vilardi J, Durand D, Powers R 1998 Opioid withdrawal in neonates after continuous infusions of morphine or fentanyl during extracorporeal membrane oxygenation. Am J Crit Care 7:364-369

140. van Straaten HL, Rademaker CM, de Vries LS 1992 Comparison of the effect of midazolam or vecuronium on blood pressure and cerebral blood flow velocity in the premature newborn. Dev Pharmacol Ther 19:191-195

141. Harte GJ, Gray PH, Lee TC, Steer PA, Charles BG 1997 Haemodynamic responses and population pharmacokinetics of midazolam following administration to ventilated, preterm neonates. J Paediatr Child Health 33:335-338

142. Burtin P, Daoud P, Jacqz-Aigrain E, Mussat P, Moriette G 1991 Hypotension with midazolam and fentanyl in the newborn. Lancet 337:1545-1546

143. Bouwmeester NJ, Anand KJ, van Dijk M, Hop WC, Boomsma F, Tibboel D 2001 Hormonal and metabolic stress responses after major surgery in children aged $0-3$ years: a double-blind, randomized trial comparing the effects of continuous versus intermittent morphine. Br J Anaesth 87:390-399

144. Lynn AM, Nespeca MK, Bratton SL, Shen DD 2000 Intravenous morphine in postoperative infants: intermittent bolus dosing versus targeted continuous infusions. Pain 88:89-95

145. Bouwmeester NJ, Hop WC, van Dijk M, Anand KJ, van den Anker JN, Tibboel D 2003 Postoperative pain in the neonate: age-related differences in morphine requirements and metabolism. Intensive Care Med 29:2009-2015

146. Vaughn PR, Townsend SF, Thilo EH, McKenzie S, Moreland S, Denver KK 1996 Comparison of continuous infusion of fentanyl to bolus dosing in neonates after surgery. J Pediatr Surg 31:1616-1623

147. Howard CR, Howard FM, Weitzman ML 1994 Acetaminophen analgesia in neonatal circumcision: the effect on pain. Pediatrics 93:641-646

148. van der Marel CD, Peters JW, Bouwmeester NJ, Jacqz-Aigrain E, van den Anker JN, Tibboel D 2007 Rectal acetaminophen does not reduce morphine consumption after major surgery in young infants. Br J Anaesth 98:372-379

149. Allegaert K, Rayyan M, De Rijdt T, Van Beek F, Naulaers G 2008 Hepatic tolerance of repeated intravenous paracetamol administration in neonates. Paediatr Anaesth 18:388-392
150. Papacci P, De Francisci G, Iacobucci T, Giannantonio C, De Carolis MP, Zecca E, Romagnoli C 2004 Use of intravenous ketorolac in the neonate and premature babies. Paediatr Anaesth 14:487-492

151. Carbajal R, Eble B, Anand KJ 2007 Premedication for tracheal intubation in neonates: confusion or controversy? Semin Perinatol 31:309-317

152. Barrington KJ, Byrne PJ 1998 Premedication for neonatal intubation. Am J Perinatol 15:213-216

153. Dempsey EM, Al Hazzani F, Faucher D, Barrington KJ 2006 Facilitation of neonatal endotracheal intubation with mivacurium and fentanyl in the neonatal intensive care unit. Arch Dis Child Fetal Neonatal Ed 91:F279-F282

154. Roberts KD, Leone TA, Edwards WH, Rich WD, Finer NN 2006 Premedication for nonemergent neonatal intubations: a randomized, controlled trial comparing atropine and fentanyl to atropine, fentanyl, and mivacurium. Pediatrics 118:1583-1591

155. Lemyre B, Doucette J, Kalyn A, Gray S, Marrin ML 2004 Morphine for elective endotracheal intubation in neonates: a randomized trial [ISRCTN43546373]. BMC Pediatr 4:20

156. Oei J, Hari R, Butha T, Lui K 2002 Facilitation of neonatal nasotracheal intubation with premedication: a randomized controlled trial. J Paediatr Child Health 38:146150

157. Pokela ML, Koivisto M 1994 Physiological changes, plasma beta-endorphin and cortisol responses to tracheal intubation in neonates. Acta Paediatr 83:151-156

158. Welzing L, Kribs A, Huenseler C, Eifinger F, Mehler K, Roth B 2009 Remifentanil for INSURE in preterm infants: a pilot study for evaluation of efficacy and safety aspects. Acta Paediatr 98:1416-1420

159. Walter-Nicolet E, Flamant C, Negrea M, Parat S, Hubert P, Mitanchez D 2007 Premedication before tracheal intubation in French neonatal intensive care units and delivery rooms. Arch Pediatr 14:144-149

160. Carbajal R, Rousset A, Danan C, Coquery S, Nolent P, Ducrocq S, Saizou C, Lapillonne A, Granier M, Durand P, Lenclen R, Coursol A, Hubert P, de Saint Blanquat L, Boelle PY, Annequin D, Cimerman P, Anand KJ, Breart G 2008 Epidemiology and treatment of painful procedures in neonates in intensive care units. JAMA 300:60-70

161. Stevens B, Yamada J, Ohlsson A 2004 Sucrose for analgesia in newborn infants undergoing painful procedures. Cochrane Database Syst Rev CD001069

162. Jain S, Kumar P, McMillan DD 2006 Prior leg massage decreases pain responses to heel stick in preterm babies. J Paediatr Child Health 42:505-508

163. Freire NB, Garcia JB, Lamy ZC 2008 Evaluation of analgesic effect of skin-to-skin contact compared to oral glucose in preterm neonates. Pain 139:28-33

164. Bellieni CV, Cordelli DM, Marchi S, Ceccarelli S, Perrone S, Maffei M, Buonocore G 2007 Sensorial saturation for neonatal analgesia. Clin J Pain 23:219-221

165. Scott CS, Riggs KW, Ling EW, Fitzgerald CE, Hill ML, Grunau RV, Solimano A, Craig KD 1999 Morphine pharmacokinetics and pain assessment in premature newborns. J Pediatr 135:423-429

166. Carbajal R, Lenclen R, Jugie M, Paupe A, Barton BA, Anand KJ 2005 Morphine does not provide adequate analgesia for acute procedural pain among preterm neonates. Pediatrics 115:1494-1500

167. Saarenmaa E, Huttunen P, Leppaluoto J, Fellman V 1996 Alfentanil as procedural pain relief in newborn infants. Arch Dis Child Fetal Neonatal Ed 75:F103-F107

168. Taddio A, Lee C, Yip A, Parvez B, McNamara PJ, Shah V 2006 Intravenous morphine and topical tetracaine for treatment of pain in [corrected] neonates undergoing central line placement. JAMA 295:793-800

169. Lago P, Tiozzo C, Boccuzzo G, Allegro A, Zacchello F 2008 Remifentanil for percutaneous intravenous central catheter placement in preterm infant: a randomized controlled trial. Paediatr Anaesth 18:736-744

170. Shah V, Taddio A, Ohlsson A 1998 Randomised controlled trial of paracetamol for heel prick pain in neonates. Arch Dis Child Fetal Neonatal Ed 79:F209-F211

171. Peters JW, Schouw R, Anand KJ, van Dijk M, Duivenvoorden HJ, Tibboel D 2005 Does neonatal surgery lead to increased pain sensitivity in later childhood? Pain 114:444-454

172. Botting N, Powls A, Cooke RW, Marlow N 1997 Attention deficit hyperactivity disorders and other psychiatric outcomes in very low birthweight children at 12 years. J Child Psychol Psychiatry 38:931-941

173. Whitfield MF, Grunau RE 2000 Behavior, pain perception, and the extremely low-birth weight survivor. Clin Perinatol 27:363-379 